\title{
REVIEW
}

Open Access

\section{Evidence-based management of acute rhinosinusitis with herbal products}

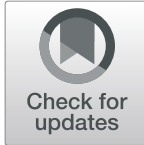

\author{
Claus Bachert
}

\begin{abstract}
Background: The overuse of antibiotics for unjustified indications such as the management of acute uncomplicated rhinosinusitis has contributed to the emergence of antibiotic-resistant strains of bacteria and prompted the need for alternative treatments. This review assesses the quality of evidence for the management of acute rhinosinusitis with herbal products, with the goal of positioning them among other treatments and identifying future research directions. The MEDLINE database was searched for randomized controlled trials with Sinupret ${ }^{\oplus}$, Pelargonium sidoides extract, Cyclamen europaeum (CE), cineole, and GeloMyrtol ${ }^{\oplus}$. Searches with Nacetylcysteine and mometasone furoate nasal spray (MFNS) were performed to compare the strength of evidence of herbal products to these conventional products, which are indicated for acute rhinosinusitis.

Main body: Evidence was strongest for Sinupret, followed by Pelargonium sidoides extract. Their use in acute rhinosinusitis is supported by randomized placebo-controlled trials demonstrating both clinical efficacy and safety. Comparative data with conventional treatments such as topical glucocorticosteroids were found only for Sinupret and suggested comparable efficacy in a small study.

For other herbal products, the overall level of evidence was low. The search retrieved two small-scale placebocontrolled randomized studies with CE nasal spray. The two trials were not powered to draw conclusions about the safety and efficacy of CE nasal spray and reported a lack of efficacy with CE on symptom reduction. Only one randomized placebo-controlled trial was identified for GeloMyrtol and cineole. These suggested an improvement in acute rhinosinusitis symptoms with both products, but the results warrant replication in larger trials.

Studies directly comparing herbal products are scarce; one randomized trial has compared cineole with Sinupret, but the results need confirmation in further studies.

Studies with N-acetylcysteine are limited to small-scale clinical trials, while MFNS is supported by a strength of evidence comparable to Sinupret in this indication.

Conclusion: State-of-the-art studies demonstrating the efficacy and safety of herbal products for the management of acute rhinosinusitis are available. Given that the evidence for Sinupret is the strongest and comparable to that of a widely available topical corticosteroid, MFNS, Sinupret may be considered for the management of acute uncomplicated rhinosinusitis.
\end{abstract}

Keywords: Acute rhinosinusitis, Herbal product, Conventional treatment, Antibiotic 


\section{Introduction}

Acute rhinosinusitis, a common infection of the upper respiratory tract, is associated with a significant impact on quality of life and high socioeconomic costs $[1,2]$. Guidance on the treatment of acute rhinosinusitis is clear. The European position paper on rhinosinusitis and nasal polyps (EPOS) 2012 recommends antibiotics for sinusitis of bacterial origin only [1], and the International Consensus Statement on Allergy and Rhinology: Rhinosinusitis (ICAR:RS) recommends a conservative approach to the use of antibiotics on the grounds that acute rhinosinusitis even of bacterial origin has a high spontaneous resolution rate [3]. In cases of acute viral rhinosinusitis, guidelines support the use of topical steroids, antihistamines and ipratropium bromide (level of evidence Ia), aspirin/non-steroidal anti-inflammatory drug (level of evidence Ib), and herbal medicines (level of evidence Ib). Systemic steroids, however, are only recommended in complicated sinusitis [3].

Despite the existence of these recommendations on the use of antibiotics, acute rhinosinusitis is frequently treated with antibiotics, contributing to the global emergence of antibiotic-resistant strains of bacteria [4]. One way of addressing the overuse of antibiotics in this scenario is to identify alternative treatments for rhinosinusitis that treat the infection and control symptoms.

Herbal products first triggered the interest of clinicians in the 1990s, and there has been a drive to perform further studies on them ever since [5]. Until the 1990s, evidence for the use of herbal products in acute rhinosinusitis remained largely anecdotal. However, in the past 20 years, randomized controlled trials in rhinosinusitis have been performed with a number of herbal products [6-8].

This review aims to assess the level and quality of evidence for the management of acute rhinosinusitis with herbal products and review their position in the context of other treatments. To this end, we have selected four herbal products for which high-level evidence was available from at least one double-blind randomized clinical trial involving approximately 100 patients or more, either versus placebo or in comparison with another active treatment: Sinupret ${ }^{\oplus}$, Pelargonium sidoides extract, Cyclamen europaeum (CE), cineole, and GeloMyrtol forte ${ }^{\oplus}$. To provide context for these data, we compared the strength of evidence of herbal products with that of the two synthetic treatments currently indicated for the management of acute rhinosinusitis, $\mathrm{N}$-acetylcysteine and mometasone furoate. A further objective was to identify current knowledge gaps and future research directions for herbal products in managing acute rhinosinusitis.

The MEDLINE database was searched in January 2019 for studies with Sinupret, Pelargonium sidoides extract,
CE, cineole, GeloMyrtol, N-acetylcysteine, and mometasone furoate, which have been characterized in welldesigned, double-blind, randomized controlled trials. We have not included Petasites hybridus (butterbur), Aller-7 or Chinese herbal medicines for allergic rhinitis, as these have been assessed previously and the findings published by Guo et al. [6].

The structure of the search strings was 'acute rhinosinusitis' or 'acute rhinitis' or 'acute sinusitis' and '[product name]'. The search was intended to identify randomized controlled trials, however, when none were available, other study types were included.

\section{Sinupret}

Sinupret has been available for the treatment of sinusitis since 1934 [9]. It is a herbal preparation containing a mixture of Gentianae radix, Primulae flos cum calycibus, Sambuci flos, Rumicis herba, and Verbenae herba [10]. Preclinical studies suggest that Sinupret has beneficial effects in acute rhinosinusitis due to its antiviral, secretolytic, anti-inflammatory, and immunomodulatory properties [11]. Sinupret is available as a low-dose formulation (BNO 101) and as a high-dose formulation (BNO 1016) [12, 13]. The literature search identified three clinical trials, a pooled analysis of two clinical trials, and a non-randomized study investigating Sinupret in acute rhinosinusitis. Table 1 summarizes clinical data for Sinupret.

\section{Sinupret versus placebo}

Neubauer and März tested the efficacy and toxicity of Sinupret (BNO 101) in a randomized double-blind placebo-controlled trial [9]. The trial included 160 patients with a diagnosis of acute bacterial sinusitis $(n=81$ in the Sinupret group and $n=79$ in the placebo group). Sinupret or placebo were given as two sugar-coated tablets three times a day for 2 weeks alongside an antibiotic and a decongestant. Overall, patients in the Sinupret group had significantly better primary outcomes - radiographic findings and patient assessment of the therapy at the end of treatment - than patients receiving placebo. Likewise, patients in the Sinupret group reported a significant improvement in secondary outcomes, including mucosal swelling, nasal obstruction and headache, compared with patients in the placebo group. No significant toxicities were reported in either study group. The main limitation of this trial was the inclusion of male participants only.

A meta-analysis by Melzer et al., including published and unpublished data with BNO 101, confirmed the results of the trial [12]. The studies included in the metaanalysis also had a predominantly male population, limiting the application of the findings to a broader population. 
Table 1 Clinical studies of Sinupret

\begin{tabular}{|c|c|c|c|c|}
\hline Study & Study design & Population & Sample size & Main findings \\
\hline \multicolumn{5}{|c|}{ Sinupret versus placebo } \\
\hline $\begin{array}{l}\text { Neubauer N, } \\
\text { and März. } 1994 \\
\text { [9] }\end{array}$ & $\begin{array}{l}\text { Double-blind } \\
\text { clinical trial }\end{array}$ & $\begin{array}{l}\text { Patients with acute bacterial sinusitis } \\
\text { showing an opacification of the plain } \\
\text { sinus radiogram }\end{array}$ & $\begin{array}{l}n=81 \text { with } \\
\text { Sinupret } \\
\text { (BNO 101) } \\
n=79 \text { with } \\
\text { placebo }\end{array}$ & $\begin{array}{l}\text { Primary outcomes: } \\
\text { Radiographic findings and patient assessment } \\
\text { significantly favoured Sinupret to placebo } \\
\text { Exploratory outcomes: } \\
\text { Mucosal swelling, nasal obstruction, and headache } \\
\text { scores were better with Sinupret than placebo }\end{array}$ \\
\hline \multirow[t]{2}{*}{$\begin{array}{l}\text { Jund } R \text {, et al. } \\
2012[14] \text { and } \\
\text { Jund } R \text {, et al. } \\
2015[15]\end{array}$} & $\begin{array}{l}\text { Double-blind } \\
\text { clinical trial }\end{array}$ & $\begin{array}{l}\text { Patients with a diagnosis of acute viral } \\
\text { rhinosinusitis confirmed by } \\
\text { ultrasonography of the maxillary } \\
\text { sinuses }\end{array}$ & $\begin{array}{l}\text { ITT analysis } \\
{[14]} \\
n=190 \text { with } \\
\text { Sinupret } \\
\text { (BNO 1016) } \\
n=190 \text { with } \\
\text { placebo }\end{array}$ & $\begin{array}{l}\text { Primary outcome: } \\
\text { The number of patients with investigator-assessed } \\
\text { MSS } \leq 1 \text { was } 48.4 \% \text { in the Sinupret group and } 35.8 \% \\
\text { in the placebo group } \\
(p=0.0063) \text {. The NNT for patients to have MSS } \leq 1 \\
\text { was } 8 \\
\text { Secondary outcomes: } \\
\text { Patient-assessed MSS, SNOT-20 GAV, and ultrasonog- } \\
\text { raphy imaging were more favourable with Sinupret } \\
\text { than placebo }\end{array}$ \\
\hline & & & $\begin{array}{l}\text { PP analysis } \\
{[14,15]} \\
n=147 \text { with } \\
\text { Sinupret } \\
\text { (BNO 1016) } \\
n=153 \text { with } \\
\text { placebo }\end{array}$ & $\begin{array}{l}\text { Secondary outcome: } \\
\text { The investigator-assessed MSS score was } 2.07 \pm 0.18 \\
\text { in the Sinupret group and } 3.47 \pm 0.28 \text { in the placebo } \\
\text { group ( } p=0.0001 \text { ). The NNT for patients to have } \\
\text { MSS } \leq 1 \text { was } 7\end{array}$ \\
\hline $\begin{array}{l}\text { Jund R, et al. } \\
2015 \text { [13] }\end{array}$ & $\begin{array}{l}\text { Pooled analysis } \\
\text { of two } \\
\text { randomized } \\
\text { clinical trials }\end{array}$ & $\begin{array}{l}\text { Patients with a diagnosis of acute viral } \\
\text { rhinosinusitis confirmed by } \\
\text { ultrasonography of the maxillary } \\
\text { sinuses }\end{array}$ & $\begin{array}{l}n=294 \text { with } \\
\text { Sinupret } \\
\text { (BNO 1016) } \\
n=295 \text { with } \\
\text { placebo }\end{array}$ & $\begin{array}{l}\text { Primary outcome: } \\
\text { MSS improved during the treatment period by a } \\
\text { mean of } 10.02 \pm 1.61 \text { score points to } 2.47 \pm 2.55 \text { for } \\
\text { Sinupret and of } 9.87 \pm 1.52 \text { to } 3.63 \pm 3.63 \text { for placebo. } \\
\text { Differences between treatment groups at end of } \\
\text { therapy }(1.16 \pm 3.14 \text { score points; } p<0.0001 \text { ) was } \\
\text { statistically significant in favour of Sinupret } \\
\text { Secondary outcome: } \\
\text { Patient-assessed quality of life at the end of } \\
\text { treatment significantly favoured Sinupret ( } p=0.0015 \text { ) }\end{array}$ \\
\hline
\end{tabular}

\section{Sinupret versus conventional treatments}

\begin{tabular}{|c|c|c|c|c|}
\hline $\begin{array}{l}\text { Passali D, et al. } \\
2015[16]\end{array}$ & Open-label study & $\begin{array}{l}\text { Patients with acute sinusitis as defined } \\
\text { by EPOS } 2012 \text { guidelines }\end{array}$ & $\begin{array}{l}n=30 \text { with } \\
\text { Sinupret } \\
\text { Forte } \\
n=30 \text { with } \\
\text { fluticasone } \\
\text { furoate }\end{array}$ & $\begin{array}{l}\text { Primary outcome: } \\
\text { At Day } 14,66.7 \% \text { and } 50 \% \text { of patients had a MSS } \leq 1 \\
\text { in the Sinupret and fluticasone groups, } \\
\text { respectively } \\
\text { Secondary outcome: } \\
\text { At Day } 14 \text {, the SNOT- } 20 \text { scores were } 7.0 \text { in the Sinu- } \\
\text { pret group and } 6.5 \text { in the fluticasone group }\end{array}$ \\
\hline $\begin{array}{l}\text { Weber U, et al. } \\
2002[17]\end{array}$ & $\begin{array}{l}\text { Non-randomized } \\
\text { study }\end{array}$ & Patients with acute sinusitis & $\begin{array}{l}n=30 \text { with } \\
\text { Sinupret/ } \\
\text { Cinnabaris } 3 X \\
n=33 \text { with } \\
\text { conventional } \\
\text { therapy }\end{array}$ & $\begin{array}{l}\text { Main study outcomes } \\
\text { No clinically relevant differences were observed } \\
\text { between the two groups on investigator-defined pa- } \\
\text { tients' scores, physicians' scores and quality of life }\end{array}$ \\
\hline
\end{tabular}

EPOS European position paper on rhinosinusitis and nasal polyps, GAV German-adapted version, ITT Intent-to-treat, MSS Major symptom score, NNT Number needed to treat, PP Per-protocol, SNOT-20 Sino-nasal outcome test-20

Similar benefits of Sinupret (BNO 1016) were reported in patients with acute viral rhinosinusitis, in a robustly designed double-blind randomized controlled trial [14, 15]. In contrast to the trial conducted by Neubauer and März, patients did not receive treatments for acute rhinosinusitis other than the study drug, and there was a higher proportion of women than men in both treatment groups [14]. This trial randomized 386 patients $(n=194$ in the Sinupret group and $n=192$ in the placebo group). Patients received two tablets of Sinupret $80 \mathrm{mg}$ or placebo, three times daily for 15 days. In the intent-to-treat (ITT) population ( $n=190$ in each group), the number of patients considered to be healed (investigator-assessed major symptom score $[\mathrm{MSS}] \leq 1$ ) was significantly higher in the Sinupret group than in the placebo group $(48.4 \%$ vs. $35.8 \% ; p=0.0063)$ at the end of treatment. The number needed to treat (NNT) for patients to have MSS $\leq 1$ at the end of treatment was eight in the ITT. This result was corroborated by patient-assessed MSS, the 20-item questionnaire sino-nasal outcome test (SNOT-20) German- 
adapted version (GAV), and ultrasonography imaging. The incidence of adverse events was similar between the two groups. The per-protocol (PP) analysis of the trial gave results concurrent with the ITT analysis [14, 15]. One of the possible limitations of the trial was the way in which rhinosinusitis symptoms were rated by investigators, based on patient description, instead of a direct assessment by the patient. Results of this large trial were pooled with those of a trial with a similar design to confirm the efficacy of Sinupret in acute rhinosinusitis in a large patient population $(n=589)$ [13]. The pooled analysis confirmed previous results, with a greater improvement in MSS and quality of life outcomes in the Sinupret versus placebo group.

In summary, adequately powered randomized trials have demonstrated superiority of Sinupret versus placebo in patients with bacterial or viral rhinosinusitis. Trials of Sinupret in bacterial sinusitis almost exclusively included male patients, while trials of Sinupret in viral sinusitis included a mixed-gender study population.

\section{Sinupret versus other treatments}

A limited number of studies have provided evidence on the efficacy and safety of Sinupret versus synthetic treatments. The literature search identified one open-label study comparing Sinupret Forte with intranasal fluticasone furoate [16]. The study enrolled 60 patients with acute rhinosinusitis according to EPOS 2012 guidelines who were given either Sinupret Forte $(n=30)$ or intranasal fluticasone furoate $(n=30)$. Sinupret Forte (one tablet) was given three times a day while fluticasone furoate (two puffs in each nostrils) was given once a day for 14 days. Both Sinupret and intranasal fluticasone induced a similar improvement in MSS and SNOT-20 as evaluated by the investigator at Day 14. Patients in the Sinupret Forte group did not report any adverse events. In the fluticasone group, one patient reported epistaxis and two patients reported nasal itching. The conclusions of the study are limited by its relatively small size and open-label design.

Another study compared a combination of Sinupret and Cinnabaris $3 \mathrm{X}$ with synthetic treatment, including antibiotics, secretolytics and sympathomimetics in patients presenting with acute sinusitis or an acute exacerbation of a chronically relapsing sinusitis [17]. Although treatment differences varied depending on the endpoint, differences were not clinically relevant. The study was limited by its non-randomized design and the fact that study groups were not evenly matched before treatment administration, with the authors concluding that 'randomized trials including at least 400 patients are needed to produce valid results'.

Overall, robust head-to-head comparisons of Sinupret with conventional treatments are currently not available.
Published studies lack statistical power or were not designed to show either differences or equivalence between treatments, thereby limiting the strength of conclusions.

\section{Pelargonium sidoides extract}

The roots of Pelargonium sidoides have been used in traditional Zulu medicine for a long time, but the current synthetic form as liquid herbal extract, also known as EPs 7630 , became available only recently [18, 19]. EPs 7630 has demonstrated antiviral as well as immunomodulatory effects in vitro $[20,21]$. The literature search identified two randomized placebo-controlled trials of EPs 7630 in acute rhinosinusitis. Studies of EPs 7630 are summarized in Table 2.

\section{Pelargonium sidoides versus placebo}

Lizogub et al. and Riley et al. tested two doses of Pelargonium sidoides extract in a two-part randomized double-blind clinical trial where the standard dose of EPs 7630P was compared with placebo [22] and a high dose of EPs 7630 was compared with placebo [23]. Patients were randomly assigned to the part of the trial examining standard dose versus placebo or the part of the trial examining high dose versus placebo [23]. Once allocated to a part of the trial, patients were then randomized to either treatment group. Patients included had either two major cold symptoms and one minor cold symptom, or one major cold symptom and three minor cold symptoms. The symptoms had to be present for 24 to $48 \mathrm{~h}$. An ITT analysis was used.

The standard dose of EPs 7630 was defined as 30 drops three times daily [22]. From baseline to Day 5, the mean sum of the symptom intensity difference (SSID) in the cold intensity score (CIS) - the primary endpoint improved by $14.6 \pm 5.3$ points with the standard dose of EPs $7630(n=52)$ and $7.6 \pm 7.5$ points with placebo $(n=$ 51) $(p<0.0001)$. Likewise, patients in the standard dose EPs 7630 group reported greater improvement in individual symptoms of CIS, ability to work, and quality of life than patients in the placebo group. Two patients in the EPs 7630 group $(n=52)$ and one patient in the placebo group $(n=51)$ reported adverse events (one case of tracheitis in each group and one case of epistaxis possibly related to study drug in the EPs 7630 group).

The high dose of EPs 7630 was defined as 60 drops three times daily [23]. The mean SSID in CIS from baseline to Day 3 and from baseline to Day 5 - the primary endpoint - was $16.0 \pm 7.4$ points with the high dose of EPs 7630 group and $8.3 \pm 7.6$ points with placebo $(p<$ 0.0001). As with the standard dose, patients in the EPs 7630 group reported greater improvement in ability to work and quality of life than patients in the placebo group. Adverse events were more frequent in the highdose EPs 7630 group (15.4\%) than in the placebo group 
Table 2 Clinical studies of Pelargonium sidoides extract (EPs 7630)

\begin{tabular}{|c|c|c|c|c|}
\hline Study & Study design & Population & Sample size & Main findings \\
\hline $\begin{array}{l}\text { Lizogub } \\
\text { VG, et al. } \\
2007 \text { [22] }\end{array}$ & $\begin{array}{l}\text { Double-blind } \\
\text { randomized } \\
\text { controlled trial }\end{array}$ & $\begin{array}{l}\text { Patients with either two major cold symptoms } \\
\text { and one minor cold symptom, or one major cold } \\
\text { symptom and three minor cold symptoms. } \\
\text { Symptoms had to be present for } 24 \text { to } 48 \mathrm{~h}\end{array}$ & $\begin{array}{l}n=52 \text { with } \\
\text { EPs } 7630 \\
\text { standard dose } \\
n=51 \text { with } \\
\text { placebo [22] }\end{array}$ & $\begin{array}{l}\text { Primary outcome: } \\
\text { From baseline to Day } 5 \text {, the mean SSID improved by } \\
14.6 \pm 5.3 \text { points in the EPs } 7630 \text { group }(n=52) \text { and } \\
7.6 \pm 7.5 \text { points in the placebo group }(n=51) \\
(p<0.0001)\end{array}$ \\
\hline
\end{tabular}

Secondary outcomes:

Patients in the EPs 7630 group reported greater improvement than patients in the placebo group in individual symptoms of the CIS, ability to work and quality of life

$\begin{array}{lll}\begin{array}{l}\text { Riley DS, } \\ \text { et al. }\end{array} & \begin{array}{l}\text { Double-blind } \\ \text { randomized }\end{array} & \begin{array}{l}\text { Patients with either two major cold symptoms } \\ \text { and one minor cold symptom, or one major cold }\end{array} \\ 2018 \text { [23] } & \text { controlled trial } & \begin{array}{l}\text { symptom and three minor cold symptoms. } \\ \text { Symptoms had to be present for } 24 \text { to } 48 \mathrm{~h}\end{array}\end{array}$

Bachert Double-blind Patients with acute rhinosinusitis

$C$, et al. randomized

2009 [24] controlled trial

\section{$n=52$ with $\quad$ Primary outcome:}

EPs 7630 high The mean SSID from baseline through Day 3 to Day dose $\quad 5$ was $16.0 \pm 7.4$ points for the EPs 7630 group and

$n=52$ with $\quad 8.3 \pm 7.6$ points for placebo $(p<0.0001)$

placebo [23] Secondary outcomes:

Patients in the EPs 7630 group reported greater improvement in ability to work and quality of life

\section{$n=51$ with Primary outcome:}

EPs 7630 high The change in SSS after 7 days was greater in the dose $n=52$ with group ( 2.5 points) $(p<0.00001)$

placebo Secondary outcomes:

Quality of life, ability to work, and treatment satisfaction favoured EPs 7630 to placebo

$\begin{array}{lll}\text { Perić A, Randomized, } & \text { Patients with mild to moderate acute bacterial } \\ \text { et al. } & \text { open label rhinosinusitis }\end{array}$

Outcomes ${ }^{\mathrm{a}}$ :

Greater improvements in TSS, TES and individual symptom scores with EPs 7630 vs amoxicillin $(p<0$ .001 for all)

No differences between groups in absolute improvements of rhinorrhea score and postnasal drip score. No reported adverse events in either group.

CIS Cold intensity score, SSID Sum of symptom intensity differences, SSS Sinusitis severity score, TES Total endoscopic score, TSS Total symptom score ${ }^{a}$ No differentiation of primary or secondary outcomes reported

(5.8\%), the most frequent of which were mild epistaxis and mild epigastric discomfort. None of the adverse events reported were severe and no serious adverse events were reported.

Collectively, these data suggest that the optimal dose of EPs 7630 may be the standard dose. However, the lack of a dose-finding study, and inconsistencies in the primary endpoint definition and results obtained with the higher dose are noticeable within the article [23]. Moreover, the primary endpoints were not identical (SSID from baseline to Day 5 in the part with the standard dose versus SSID from baseline to Day 3 and from baseline to Day 5 in the part with the high dose), even though these were part of the same trial [22, 23]. Interestingly, the results of this two-part clinical trial were published 10 years apart, with the results obtained with the standard dose of EPs 7630 published first, in 2007, and the results with the high dose published in 2018.

In the meantime, another group published results of a randomized, double-blind, controlled trial comparing a high dose of EPs 7630 (as defined previously by Riley et al.) with placebo [24]. In this trial, 51 patients were allocated to EPs 7630 and 52 to placebo. After a 7-day treatment, the mean decrease in sinusitis severity score (SSS) - the primary endpoint - was greater in the EPs
7630 group (5.5 points) than in the placebo group $(2.5$ points), with a difference of 3.0 points (95\% confidence interval [CI] 2.0 to $3.9, p<0.00001)$. Patients in the EPs 7630 group also reported better quality of life and were more able to engage in work activities than patients in the placebo group, as demonstrated by secondary outcomes. Adverse events were reported by $11.8 \%$ of patients in the EPs 7630 group and $3.8 \%$ of patients in the placebo group. The most frequently reported adverse events in the active drug group, considered as study drug-related, were gastrointestinal complaints.

Overall, the two placebo-controlled trials have reported consistent efficacy and safety with high-dose EPs 7630. In both studies, two-thirds of patients were female and a comparison of the treatment groups with respect to gender, age, weight, height, and body mass index showed no difference between the treatment groups [22, 23]. However, dose-finding studies directly comparing the standard dose of EPs 7630 with the high dose would help ascertain these conclusions, as would prospective head-to-head comparisons with either conventional treatments or other herbal products. Adverse events are reported more frequently with EPs 7630 than with placebo. 


\section{Pelargonium sidoides versus other treatments}

The efficacy of EPs 7630 for the treatment of uncomplicated acute bacterial rhinosinusitis (ABRS) was recently assessed by Perić et al. [25]. In this prospective, open label, non-inferiority study, 50 patients with mild-tomoderate ABRS were randomized 1:1 to receive treatment with EPs 7630 tablets $3 \times 20 \mathrm{mg} /$ day or amoxicillin tablets $3 \times 500 \mathrm{mg} /$ day, for 10 days. Significantly greater improvements in the total symptom score, total endoscopic score, and scores of individual symptoms (nasal obstruction, rhinorrhea, postnasal drip, facial pain/pressure, loss of the sense of smell) were observed in patients treated with EPs 7630 compared with patients in the group receiving amoxicillin $(p<0.001$ for all). However, there were no significant differences between groups in the absolute improvements of rhinorrhea score and postnasal drip score. No adverse events were reported in either group, and culture analyses found fewer types of bacteria in middle meatal samples from the EPs 7630 group compared with the amoxicillin group [25].

\section{Cyclamen europaeum (CE)}

CE extract has been used for a long time in Southeast Europe for the management of nasopharyngeal diseases [26]. However, the first randomized trials assessing the efficacy and safety of this product in acute rhinosinusitis became available very recently only $[27,28]$. In its current formulation, the aqueous/alcohol CE extract contains the saponin fraction [28]. When administered intranasally, the extract causes a rapid, abundant and often painful discharge of mucus through a cholinergic reflex lasting for about $30 \mathrm{~min}$ [28, 29]. The literature search identified two double-blind randomized trials comparing $\mathrm{CE}$ nasal spray with matching placebo in acute rhinosinusitis. These two trials were subsequently included in a Cochrane meta-analysis aiming to assess the efficacy and safety of CE nasal spray in acute rhinosinusitis. Studies with CE extract are summarized in Table 3.

\section{CE versus placebo}

Patients with moderate-to-severe acute rhinosinusitis, as defined in the first EPOS guidelines, were enrolled in a double-blind randomized trial to receive either CE nasal spray $(n=48)$ or matched placebo $(n=51)$ for 15 days alongside antibiotics [27]. Each spray was administered intranasally once daily in the evening. In the ITT population, the difference in mean total rhinosinusitis symptoms score measured with a visual analogue scale after 5-7 days - the primary endpoint - was not statistically significant between the two groups. However, the reduction in facial pain and nasal endoscopic evaluation significantly favoured CE nasal spray compared with placebo. At the end of the study, patient- and investigator-rated satisfaction scores significantly favoured CE nasal spray versus placebo. No severe adverse events were reported, but patients in the $\mathrm{CE}$ group reported nasal irritation/burning more frequently than patients in the placebo group [27]. Given the lack of power calculations reported in the article, this study may not have been adequately powered for the primary endpoint.

Table 3 Clinical studies with Cyclamen europaeum nasal spray

\begin{tabular}{|c|c|c|c|c|}
\hline Study & Study design & Population & Sample size & Main findings \\
\hline $\begin{array}{l}\text { Pfaar O, et al. } 2012 \\
{[27]}\end{array}$ & $\begin{array}{l}\text { Double-blind } \\
\text { randomized } \\
\text { trial }\end{array}$ & $\begin{array}{l}\text { Patients with } \\
\text { acute } \\
\text { rhinosinusitis }\end{array}$ & $\begin{array}{l}n=48 \text { with } \\
\text { CE nasal } \\
\text { spray } \\
n=51 \text { with } \\
\text { placebo }\end{array}$ & $\begin{array}{l}\text { Primary outcome: } \\
\text { In the ITT population, the difference in mean total rhinosinusitis symptoms } \\
\text { score measured with a visual analogue scale after 5-7 days was not } \\
\text { statistically significant between the two groups } \\
\text { Secondary outcomes: } \\
\text { Only the reduction in facial pain and endoscopic evaluation significantly } \\
\text { favoured CE nasal spray compared with placebo }\end{array}$ \\
\hline $\begin{array}{l}\text { Ponikau JU, et al. } \\
2012 \text { [28] }\end{array}$ & $\begin{array}{l}\text { Double-blind } \\
\text { randomized } \\
\text { trial }\end{array}$ & $\begin{array}{l}\text { Patients with } \\
\text { acute } \\
\text { rhinosinusitis }\end{array}$ & $\begin{array}{l}n=24 \text { with } \\
\text { CE nasal } \\
\text { spray } \\
n=24 \text { with } \\
\text { placebo }\end{array}$ & $\begin{array}{l}\text { Primary outcomes: } \\
\text { The change in sinus opacification from baseline to endpoint was greater in } \\
\text { the CE nasal spray group than placebo (mean difference: } 16.32 ; 95 \% \mathrm{Cl} \text { - } \\
32.239 \text { to }-0.396) \text {. } \\
\text { However, the predose TSS was not different between the two groups } \\
\text { (mean difference: }-0.61 ; 95 \% \text { Cl: }-1.790 \text { to } 0.578 \text { ) } \\
\text { Secondary outcomes: } \\
\text { No significant differences between treatment groups were observed for } \\
\text { symptom change from baseline and mucopurulence and inflammation at } \\
\text { Day } 8\end{array}$ \\
\hline $\begin{array}{l}\text { Zalmanovici } \\
\text { Trestioreanu A, et al. } \\
2018 \text { [30] }\end{array}$ & $\begin{array}{l}\text { Cochrane } \\
\text { meta-analysis }\end{array}$ & $\begin{array}{l}\text { Patients with } \\
\text { acute } \\
\text { rhinosinusitis }\end{array}$ & $\begin{array}{l}n=147 \\
\text { participants } \\
\text { in total }\end{array}$ & $\begin{array}{l}\text { Main study outcomes: } \\
\text { None of the studies reported the primary outcomes of the meta-analysis } \\
\text { (proportion of participants whose symptoms resolved or improved at Day } \\
14 \text { and Day } 30 \text { ). Mild adverse events were more frequent with CE nasal } \\
\text { spray (50\%) than placebo (24\%) (RR: } 2.11 ; 95 \% \mathrm{Cl} 1.35 \text { to } 3.29 \text { ) }\end{array}$ \\
\hline
\end{tabular}


A smaller-scale double-blind randomized trial, carried out to inform the design of future trials, also compared CE nasal spray with placebo [28]. In this study, the proportion of female patients in both placebo and treatment arms was $69 \%$. Patients with acute rhinosinusitis were randomized to receive either placebo nasal spray $(n=$ $24)$ or CE nasal spray $(n=24)$ administered as one spray in each nostril once daily for 7 days. The change in sinus opacification from baseline to endpoint was greater in the CE nasal spray group than with placebo (mean difference: 16.32 ; $95 \%$ CI: -32.239 to $-0.396, p=0.045$ ). However, the total symptom score (TSS) was not significantly different between the two groups (mean difference: $-0.61 ; 95 \%$ CI: -1.790 to $0.578, p=0.312$ ). No differences were also observed with respect to other symptoms or endoscopic outcomes. Although the purpose of this study was to assist with the design of future clinical trials with CE nasal spray, no published or ongoing large-scale trial with $\mathrm{CE}$ nasal spray seems to be available since 2012 .

Overall, both trials have reported a consistent lack of effect of nasal $\mathrm{CE}$ on sinusitis symptoms and did not have adequate statistical power to provide robust conclusions about the safety and efficacy of CE nasal spray. It is also possible that the immediate irritative effect of CE might have compromised the blinding of treatment in both trials. The Cochrane meta-analysis published in 2018 based on these two trials concluded that the efficacy of CE is unknown, while adverse events including nasal and throat irritation, mild epistaxis, and sneezing were more frequent with $\mathrm{CE}$ nasal spray than with placebo (risk ratio [RR]: 2.11; 95\% CI 1.35 to 3.29) [30]. This meta-analysis found an overall low risk of selection, performance and detection bias in the two studies included. The authors also emphasized the need for further randomized controlled trials to evaluate the efficacy of this treatment for acute rhinosinusitis [30].

\section{GeloMyrtol forte}

GeloMyrtol forte is a distillate of a mixture of four rectified essential oils [31]. Preclinical studies have reported that this product has antioxidative, secretolytic, antiinflammatory, and antimicrobial activity [32, 33]. GeloMyrtol was first tested clinically in 1995 on healthy volunteers in a study showing its secretolytic and secretomotoric effects [34]. Randomized controlled trials have also reported the efficacy of this product in chronic and acute bronchitis $[35,36]$. The literature search identified only one double-blind randomized controlled trial with GeloMyrtol in acute rhinosinusitis, summarized in Table 4.

\section{GeloMyrtol versus placebo}

In a trial of 331 patients with uncomplicated acute sinusitis, GeloMyrtol was compared with placebo alongside another essential oil [37]. In the ITT population, changes in symptom score from baseline were greater with GeloMyrtol and the other essential oil than placebo. However, the study was potentially limited by selective outcome reporting $[7,37]$, highlighting a need for more data delineating the efficacy and tolerability profile of GeloMyrtol.

\section{Cineole}

Cineole is the main active component of GeloMyrtol [39] and the main component of eucalyptus oil [40]. Like other herbal products, cineole has anti-inflammatory and antimicrobial properties [41]. When tested independently of GeloMyrtol, it has shown activity in various respiratory conditions including asthma, chronic obstructive pulmonary disease, and acute bronchitis [42] The literature search identified one double-blind placebo-controlled randomized trial with cineole in acute rhinosinusitis, summarized in Table 4.

\section{Cineole versus placebo}

In this trial, 152 patients were randomized 1:1 to placebo $(n=76)$ or cineole $(n=76)$ [38]. Two capsules containing either cineole $(100 \mathrm{mg})$ or placebo were administered three times daily for 7 days. Baseline characteristics such as age, gender, weight, symptoms-sum-score, allergy and smoking status, were balanced between the two

Table 4 Clinical studies of GeloMyrtol and cineole

\begin{tabular}{|c|c|c|c|c|c|}
\hline Study & Product & Study design & Population & $\begin{array}{l}\text { Sample } \\
\text { size }\end{array}$ & Main findings \\
\hline $\begin{array}{l}\text { Federspil P, } \\
\text { et al. } 1997 \\
\text { [37] }\end{array}$ & GeloMyrtol & $\begin{array}{l}\text { Double-blind } \\
\text { randomized } \\
\text { clinical trial }\end{array}$ & Acute sinusitis & $n=331$ & $\begin{array}{l}\text { Main study outcomes: } \\
\text { Changes in symptom score from baseline were greater with GeloMyrtol } \\
\text { and an undefined essential oil than placebo. }\end{array}$ \\
\hline $\begin{array}{l}\text { Kehrl W, } \\
\text { et al. } 2004 \\
{[38]}\end{array}$ & Cineole & $\begin{array}{l}\text { Double-blind } \\
\text { randomized } \\
\text { clinical trial }\end{array}$ & $\begin{array}{l}\text { Acute non- } \\
\text { purulent } \\
\text { rhinosinusitis }\end{array}$ & $\begin{array}{l}n=76 \\
\text { with } \\
\text { cineole } \\
n=76 \\
\text { with } \\
\text { placebo }\end{array}$ & $\begin{array}{l}\text { Primary outcome: } \\
\text { The change in symptoms-sum-score from baseline to Day } 7 \text { was } \\
\text { greater in the cineole group }(-12.5 \pm 3.6) \text { than in the placebo group } \\
(-6.5 \pm 3.5)(p<0.0001) \text {. } \\
\text { Secondary outcome: } \\
\text { Changes in individual components of symptom-sum score were higher } \\
\text { in the cineole group than in the placebo group }\end{array}$ \\
\hline
\end{tabular}


treatment groups. A xylometazoline spray was used as concomitant therapy to alleviate nasal obstruction. The change in symptoms-sum-score from baseline to Day 7 was greater with cineole $(-12.5 \pm 3.6)$ than with placebo $(-6.5 \pm 3.5)(p<0.0001)$, as was the improvement of individual symptom scores. Rhinoscopic outcomes, including redness of mucosa, oedema, and secretion viscosity/ quantity were also better in the cineole group than in the placebo group. No patients reported adverse events in the placebo group, while five patients reported headache, ear pain, epistaxis, torsion of the foot, heartburn and exanthema in the cineole group. The authors considered heartburn and exanthema to be related to cineole. Overall, the efficacy and safety of cineole data observed in this trial warrant replication in further largescale clinical trials.

\section{Comparative studies of herbal products}

Data from head-to-head comparisons can help guide treatment decisions and help clinicians to make evidencebased decisions. Equivalence or superiority of one product versus another cannot be assumed based on cross-study comparisons and must rely on direct, comparative data.

The literature search identified one randomized trial [43] and one non-interventional study comparing herbal medicines [31]. Table 5 summarizes the comparative studies of herbal products in acute rhinosinusitis.

Tesche and colleagues conducted a double-blind randomized trial comparing a herbal preparation containing five components, possibly resembling Sinupret, with cineole [43]. Of note, this study did not clearly state using Sinupret when refering to the composition of the preparation. Furthermore, no placebo group was included in the study. The study recruited a total of 150 patients across three centres, with 75 patients randomized to each treatment group. Two capsules containing $200 \mathrm{mg}$ of cineole were given three times daily and one tablet of the 5-component herbal preparation was given three times daily. Each treatment was given for 7 days and a spray of xylometazoline was given as concomitant medication to alleviate nasal obstruction.

The change in symptom-sum score from baseline (primary endpoint in the ITT population) to Day 7 was higher in the cineole group $(-11.0 \pm 3.3)$ than in the other group $(-8.0 \pm 3.0)(p<0.0001)$. Likewise, cineole induced a greater improvement than the other preparation in each individual component of the symptomsum score at Days 4 and 7 . Improvement at Day 7 in redness of mucosa, oedema and dryness was greater with cineole than with the other preparation, confirming the effect observed on the symptom-sum score. Two patients in the cineole group and three patients in the other group reported mild side effects.

Sinupret (BNO 1016) was compared with GeloMyrtol in a non-interventional parallel group study [31]. A total of 228 patients were assigned to receive either GeloMyrtol $(n=117)$ or Sinupret $(n=111)$. The study reported comparable effectiveness of the two treatments on acute rhinosinusitis symptoms, with a more rapid recovery of facial pain with GeloMyrtol than with Sinupret. However, the study presents a significant number of weaknesses in its design and methodological approach. For example, the design is closer to that of a randomized controlled trial, and the analysis lacks the statistical support of a randomized trial such as predetermined endpoints [44].

Overall, there are few head-to-head studies of herbal products. Only one randomized double-blind trial has compared a herbal preparation containing five components resembling Sinupret with cineole, while another study comparing GeloMyrtol with Sinupret is associated with serious methodological flaws. There is a need for further randomized comparative trials with herbal products to differentiate and delineate the properties of each product.

\section{Conventional treatments for acute rhinosinusitis Mometasone furoate nasal spray versus placebo or amoxicillin}

Mometasone furoate nasal spray (MFNS) has been used since 1998 for the management of inflammatory diseases

Table 5 Comparative studies of herbal products in acute rhinosinusitis

\begin{tabular}{|c|c|c|c|c|}
\hline Study & Study design & Population & Sample size & Main findings \\
\hline $\begin{array}{l}\text { Tesche S, } \\
\text { et al. } 2008 \\
\text { [43] }\end{array}$ & $\begin{array}{l}\text { Double-blind } \\
\text { randomized } \\
\text { clinical trial }\end{array}$ & Patients suspected of having acute rhinosinusitis & $\begin{array}{l}n=75 \text { with } 5- \\
\text { component } \\
\text { herbal } \\
\text { preparation } \\
n=75 \text { with } \\
\text { cineole }\end{array}$ & $\begin{array}{l}\text { Primary outcome: } \\
\text { The change in symptom-sum score from baseline } \\
\text { to Day } 7 \text { was higher in the cineole group }(- \\
11.0 \pm 3.3) \text { than in the other group }(-8.0 \pm 3.0) \\
(p<0.0001) \text {. } \\
\text { Secondary outcome: } \\
\text { Changes in individual components of symptom- } \\
\text { sum score were higher in the cineole group than } \\
\text { in the other group. }\end{array}$ \\
\hline $\begin{array}{l}\text { Gottschlich } \\
\text { S, et al. } \\
2018[31]\end{array}$ & $\begin{array}{l}\text { Non- } \\
\text { interventional } \\
\text { study }\end{array}$ & $\begin{array}{l}\text { Patients with a recommendation for treatment } \\
\text { with GeloMyrtol or Sinupret and with a diagnosis } \\
\text { of acute rhinosinusitis based on EPOS guidelines }\end{array}$ & $\begin{array}{l}n=117 \text { with } \\
\text { GeloMyrtol } \\
n=111 \text { with } \\
\text { Sinupret (BNO } \\
1016 \text { ) }\end{array}$ & $\begin{array}{l}\text { Overall, GeloMyrtol and Sinupret had comparable } \\
\text { effectiveness. The study presents with } \\
\text { methodological flaws. }\end{array}$ \\
\hline
\end{tabular}


of the nose [45]. Mometasone furoate is a glucocorticosteroid indicated for rhinitis and acute rhinosinusitis in some countries, as well as several other conditions including asthma, skin disorders, and phimosis [45]. In acute rhinosinusitis, the anti-inflammatory properties of mometasone furoate are thought to mediate its beneficial effects [45]. The literature search identified three clinical trials of mometasone furoate in acute rhinosinusitis, one Cochrane meta-analysis, and two exploratory analyses of the same trial. These studies are summarized in Table 6.

In one double-blind, placebo-controlled trial, patients with a history of sinusitis episodes and acute rhinosinusitis at the time of enrolment were randomized to receive either MFNS $400 \mu \mathrm{g}$ twice daily $(n=200)$ or placebo $(n=207)$ as adjunctive treatments to amoxicillin for 21 days [46]. The mean decrease in total symptom score (TSS) from baseline to Day 15 - the primary endpoint - was greater in the MFNS group (5.87) than in the placebo group (5.05) $(p \leq 0.01)$. The decrease in TSS from Day 16 to Day 21 was also higher in the MFNS group (7.90) than in the placebo group $(6.52)(\mathrm{p} \leq 0.01)$. Individual symptoms such as congestion, facial pain or headache improved significantly more with MFNS than with placebo from Day 16 to Day 21. However, symptoms such as rhinorrhea, post-nasal drip, or cough were not significantly different between the MFNS and placebo groups. In both treatment groups, most adverse events were mild or moderate.

Minimizing the systemic activity of intranasal steroids is an important consideration to reduce the risk of hypothalamic pituitary adrenal (HPA) axis suppression. In a subsequent double-blind, randomized clinical trial, a lower dose of MFNS (200 $\mu$ g twice daily, $n=318$ ) was compared with the dose of MFNS used previously ( $400 \mu \mathrm{g}$ twice daily, $n=324$ ) or placebo $(n=325)$, again in combination with antibiotics [47]. The decrease in TSS from baseline to Day 15 - the primary endpoint was minimally greater with MFNS $200 \mu \mathrm{g}(5.89, p=$ 0.014 versus placebo) and MFNS $400 \mu \mathrm{g}(5.86, p=0.017$ versus placebo) than with placebo (5.22). The differences between the three groups persisted from baseline to Day 21. Likewise, individual symptom scores such as congestion, facial pain, rhinorrhea and post-nasal drip showed greater improvement with MFNS than with placebo. Most adverse events were mild or moderate in intensity, but included headache and epistaxis. The cosyntropin stimulation test indicated the absence of suppression of the HPA axis with both doses of MFNS.

As the two previous trials compared MFNS as an adjunct to amoxicillin, the double-blind, double-dummy trial in 2005 by Meltzer et al. compared MFNS, amoxicillin, and placebo all given as monotherapy [48]. Patients were randomized to receive MFNS $200 \mu \mathrm{g}$ once daily $(n=243)$, MFNS $200 \mu \mathrm{g}$ twice daily $(n=235)$, amoxicillin three times daily $(n=251)$, or placebo $(n=$ 252). At last visit, differences in MSS from baseline in the ITT population - the primary endpoint - were significantly greater with MFNS twice daily than with placebo $(p<0.001)$ and amoxicillin $(p=0.002)$. At last visit, MFNS once daily was superior to placebo $(p=0.018)$ but similar to amoxicillin $(p=0.193)$. The difference in MSS from baseline was similar with amoxicillin and placebo $(p=0.275)$. Fewer patients experienced treatment failure with MFNS twice daily (4.7\%) than with MFNS once daily (10.3\%), amoxicillin (7.2\%), or placebo $(10.7 \%)$. The study confirmed that antibiotics are not indicated in acute rhinosinusitis. Most adverse events were mild or moderate and considered to be related to study drugs. Exploratory analyses of this trial showed that MFNS twice daily was associated with better quality of life scores than placebo [49] and more minimalsymptom days than placebo or amoxicillin [50]. Improved efficacy with the higher dose of MFNS was confirmed in a Cochrane meta-analysis [51]. MFNS $400 \mu \mathrm{g}$ daily was superior to placebo for symptom resolution or improvement (RR 1.10; 95\% CI 1.02 to $1.18, p=0.0093$ ) while MFNS $200 \mu \mathrm{g}$ daily was similar to placebo (RR 1.04; $95 \%$ CI 0.98 to 1.11, $p=0.19$ ) [51].

\section{$\mathrm{N}$-acetylcysteine versus placebo}

Currently, the two main indications for $\mathrm{N}$-acetylcysteine are chronic obstructive pulmonary disease and paracetamol overdose [43, 44]. It is also of potential interest for the management of acute rhinosinusitis due to its antimicrobial activity, ability to interfere with biofilm formation, and its mucolytic and antioxidant action [52, 53]. The literature search identified two clinical trials of $\mathrm{N}$ acetylcysteine in acute rhinosinusitis, and these are summarized in Table 7.

One small double-blind randomized trial $(n=39)$ compared $\mathrm{N}$-acetylcysteine with placebo combined with amoxicillin-clavulanic acid, pseudoephedrine, and normal saline nasal drops [54]. The authors found that Nacetylcysteine did not affect the Lund-Mackay score used for radiologic staging of sinusitis and it was concluded that the addition of $\mathrm{N}$-acetylcysteine to conventional treatment has no benefits in acute sinusitis.

In another trial, where only the investigators were blinded to treatment, $\mathrm{N}$-acetylcysteine was compared with ambroxol, another secretolytic agent [8]. Patients included in this randomized study had recurrent acute rhinosinusitis with a negative microbiological test and received flunisolide $0.1 \%$ combined with either $\mathrm{N}$ acetylcysteine $(n=75)$ or ambroxol $(n=75)$ intranasally twice daily for 20 days. In the ITT population, the improvement in sinusitis-related symptoms was greater in the $\mathrm{N}$-acetylcysteine group than in the ambroxol group. The authors reported a higher proportion of patients 
Table 6 Clinical studies of mometasone furoate

\begin{tabular}{llll}
\hline Study & Study design & Population & Sample size \\
\hline Meltzer EO, et al. & Double-blind randomized trial & Patients with & $n=200$ with \\
2000 [46] & & acute & MFNS $400 \mu g$ \\
& rhinosinusitis & twice daily \\
& & $n=207$ with \\
& & placebo
\end{tabular}

Nayak AS, et al. Double-blind randomized trial

Meltzer EO, et al. Double-blind randomized trial 2005 [48]

Bachert C, et al. 2007 [49]

Meltzer $\mathrm{EO}$, et al. 2012 [50] 2002 [47] Exploratory analysis of the
double-blind randomized trial by
Meltzer EO et al. 2005

$\begin{array}{ll}\text { Patients with } & n=325 \text { with } \\ \text { acute } & \text { placebo } \\ \text { rhinosinusitis } & n=318 \text { with } \\ & \text { MFNS } 200 \mu \mathrm{g} \\ & \text { twice daily } \\ & n=324 \text { with } \\ & \text { MFNS } 400 \mu \mathrm{g} \\ & \text { twice daily }\end{array}$

Patients with $n=243$ with acute MFNS $200 \mu \mathrm{g}$ rhinosinusitis once daily $n=235$ with MFNS $200 \mu \mathrm{g}$ twice daily $n=251$ with amoxicillin three times daily $n=252$ with placebo

Patients with $n=243$ with acute MFNS $200 \mu \mathrm{g}$ rhinosinusitis once daily $n=235$ with MFNS $200 \mu \mathrm{g}$ twice daily $n=251$ with amoxicillin three times daily $n=252$ with placebo

Patients with $n=240$ with acute MFNS $200 \mu \mathrm{g}$ rhinosinusitis once daily $n=233$ with MFNS $200 \mu \mathrm{g}$ twice daily $n=248$ with amoxicillin $n=246$ with placebo

$\begin{array}{llll}\text { Zalmanovici } & \text { Cochrane meta-analysis } & \text { Patients with } & n=1943 \\ \text { Trestioreanu A, } & & \text { acute } & \text { patients } \\ \text { et al. 2013 [51] } & \text { rhinosinusitis } & \end{array}$

\section{Main findings}

Primary outcome:

From Day 1 to Day 15, mean TSS for patients receiving MFNS $400 \mu \mathrm{g}$ twice daily decreased by 5.87 (50.5\%), compared with a decrease of $5.05(44.4 \%)$ in patients receiving placebo $(p \leq 0.01)$

\section{Secondary outcomes:}

Individual symptom scores showed consistently greater improvement for patients treated with MFNS compared with placebo treatment, although relief of individual symptoms varied. Larger proportions of patients in the MFNS treatment group than in the placebo group showed improvements at Day 21

\section{Primary outcome:}

Treatment with MFNS $200 \mu \mathrm{g}$ or $400 \mu \mathrm{g}$, twice daily, produced significantly greater improvements in total symptoms score from Day 1 to Day 15 than placebo (5.89, $p=0.014$ and $5.86, p=0.017$ versus 5.22 with placebo) Secondary outcomes:

Individual symptom scores showed consistently greater improvement for patients treated with either dose of MFNS compared with placebo. Both doses of MFNS were well tolerated. Cosyntropin stimulation showed no evidence of hypothalamic-pituitary-adrenal axis suppression.

\section{Primary outcome:}

The difference in MSS from baseline with MFNS twice daily was significantly superior to placebo $(p<0.001)$ and amoxicillin ( $p=0.002)$

\section{Secondary outcomes:}

Global response to treatment was greater with MFNS twice daily than with amoxicillin $(p=0.013)$ and placebo $(p=$ 0.001). All treatments had an acceptable tolerability profile

\section{Main study outcomes:}

There was a clinically meaningful $(\geq 0.8)$ improvement (reduction) in LS mean total scores on the SNOT-20 questionnaire in all four treatment groups at Day 15, but the only significantly greater improvement was with MFNS twice daily versus placebo $(p=0.047)$

\section{Main study outcomes:}

Patients receiving MFNS twice daily had more minimalsymptom day than patients treated with placebo $(62.69 \%$ vs. $50.33 \%, p<0.0001)$ or amoxicillin $(62.69 \%$ vs. $54.35 \%$, $p=0.0040)$.

Patients receiving MFNS once daily experienced a not significantly greater percentage of minimal-symptom days than those receiving placebo $(54.72 \%$ vs. $50.33 \%, p=$ $0.1286)$ or amoxicillin $(54.72 \%$ vs. $54.35 \%, p=0.8982)$

\section{Primary outcome:}

MFNS $400 \mu \mathrm{g}$ daily was superior to placebo for symptom resolution or improvement (RR 1.10; $95 \% \mathrm{Cl} 1.02$ to 1.18 , $p=0.0093)$ while MFNS $200 \mu \mathrm{g}$ daily was similar to placebo (RR $1.04 ; 95 \%$ Cl 0.98 to $1.11, p=0.19$ )

\section{Secondary outcome:}

No significant adverse events were reported 
Table 7 Clinical studies of N-acetylcysteine

\begin{tabular}{|c|c|c|c|c|}
\hline Study & Study design & Population & Sample size & Main findings \\
\hline $\begin{array}{l}\text { Bahtouee M, } \\
\text { et al. } 2017 \\
{[54]}\end{array}$ & $\begin{array}{l}\text { Double-blind } \\
\text { controlled } \\
\text { trial }\end{array}$ & $\begin{array}{l}\text { Subacute sinusitis } \\
\text { confirmed with } C T\end{array}$ & $\begin{array}{l}n=18 \text { with } \\
\text { acetylcysteine } \\
n=21 \text { with placebo }\end{array}$ & $\begin{array}{l}\text { Main study outcome: } \\
\text { No differences between groups were observed on the Lund-Mackay } \\
\text { score after treatment }\end{array}$ \\
\hline $\begin{array}{l}\text { Macchi A, } \\
\text { et al. } 2012 \text { [8] }\end{array}$ & $\begin{array}{l}\text { Single-blind } \\
\text { randomized } \\
\text { trial }\end{array}$ & $\begin{array}{l}\text { Patients with } \\
\text { recurrent acute } \\
\text { rhinosinusitis }\end{array}$ & $\begin{array}{l}n=75 \text { with } \\
\text { ambroxol and } \\
\text { flunisolide } \\
n=75 \text { with } \mathrm{N} \text { - } \\
\text { acetylcysteine and } \\
\text { flunisolide }\end{array}$ & $\begin{array}{l}\text { Primary outcome } \\
\text { All the symptoms } \\
\text { assessed in the clinical efficacy analysis had a severity reduction in both } \\
\text { treatment groups } \\
\text { Exploratory analysis: } \\
\text { In the ITT population, the proportion of patients presenting an } \\
\text { improvement at the end of treatment was } 82.67 \% \text { vs. } 50.67 \% \text { in the } \mathrm{N} \text { - } \\
\text { acetylcysteine and ambroxol groups, respectively }(p<0.0001 \text { ) }\end{array}$ \\
\hline
\end{tabular}

with improvement at the end of treatment in the $\mathrm{N}$ acetylcysteine group (82.67\%) than in the ambroxol group $(50.67 \%)(p<0.0001)$. At Months 3 and 6, the number of rhinosinusitis exacerbations after the previous episode was also lower in the $\mathrm{N}$-acetylcysteine group than in the ambroxol group. The proportion of patients reporting adverse events was lower in the $\mathrm{N}$ acetylcysteine group (18.67\%) than in the ambroxol group (52\%). The main limitations of this study relate to its open-label design, the lack of clearly defined endpoints, and the lack of comparability of both treatment groups at baseline.

Overall, evidence for the use of $\mathrm{N}$-acetylcysteine in acute rhinosinusitis is limited to small-scale clinical trials whose designs do not enable firm conclusions on the efficacy of $\mathrm{N}$-acetylcysteine in this indication.

\section{Conclusion}

A range of herbal products have been evaluated for treating acute rhinosinusitis in randomized clinical trials. Sinupret is supported with the strongest evidence base, including adequately powered multicenter clinical trials, followed by EPs 7630, which is supported by smaller studies. Across the range of other herbal products, including CE nasal spray, GeloMyrtol, and cineole, only one randomized trial is available at best for each product. Furthermore, each trial identified in this review was conducted in a single country without power calculations and a small number of participants. Ideally, adequately powered international multicenter trials would be required to confirm or discredit findings and provide further credibility for these products.

Among synthetic treatments described in this review, MFNS is supported with the strongest evidence. Interestingly, the evidence for Sinupret appears to be as strong as that for synthetic treatments, such as MFNS. Although cross-trial comparisons cannot be a substitute for direct comparisons, clinical trials of Sinupret and MFNS suggest comparable efficacy of these two products. However, patients may prefer the herbal over the 'steroid' approach.
The choice between synthetic treatment or herbal medicine is made difficult by the lack of comparative studies of herbal products with conventional medicines. Indeed, most trials conducted with herbal products have been placebo-controlled trials. Currently, only one underpowered study comparing Sinupret with fluticasone furoate is available [16]. Equally, there are not enough data of sufficient quality available to guide an evidence-based approach when choosing between different herbal products. To the best of our knowledge, only one head-to-head comparison of herbal products is available, stressing the need for further prospective trials comparing herbal products [43]. A separate study comparing Sinupret with GeloMyrtol does not allow a firm conclusion to be drawn on the efficacy of either product, due to its design [31].

Sinupret (BNO 1016) is the sole herbal product for which evidence from well-designed, randomized controlled studies with sufficient power is available. In the context of antibiotics misuse, selected herbal medicines are promising alternatives to conventional treatments and should be considered for the management of acute uncomplicated rhinosinusitis.

\section{Abbreviations}

A(B)RS: Acute (bacterial) rhinosinusitis; CE: Cyclamen europaeum; Cl: Confidence interval; CIS: Cold intensity score; CT: Computed tomography; EPOS: European position paper on rhinosinusitis and nasal polyps; GAV: German-adapted version; HPA axis: Hypothalamic pituitary adrenal axis; INCS: Intranasal corticosteroid; ITT: Intent-to-treat; LS: Least squares; MSS: Major symptom score; MFNS: Mometasone furoate nasal spray; NNT: Number needed to treat; PP: Per protocol; RR: Risk ratio; SNOT 20 : Sino-nasal outcome test; SSS: Sinusitis severity score; SSID: Sum of the symptom intensity difference; TES: Total endoscopic score; TSS: Total symptom score

\section{Acknowledgements}

Medical writing assistance provided by Dr. Thierry Deltheil of Synergy Vision Ltd. (London, UK).

Author's contributions

$\mathrm{CB}$ defined the scope of the review and revised the draft critically for key intellectual content. CB approved the final version to be published. 


\section{Authors' information}

CB is Professor, Chief of Clinics and Head of the Upper Airways Research Laboratory at the Ghent University Hospital, Ghent, Belgium. He contributes to the generation of the EPOS and ARIA guidelines for sinusitis and rhinitis.

\section{Funding}

Medical writing assistance was funded by Bionorica.

\section{Availability of data and materials}

Not applicable.

\section{Ethics approval and consent to participate}

Not applicable.

\section{Consent for publication}

Not applicable.

\section{Competing interests}

CB has received financial support or served as a consultant for Sanofi, GSK, Astra-Zeneca, Novartis, Bionorica, Asit Biotech, Stallergenes Greer, and ALK.

Received: 25 July 2019 Accepted: 23 November 2020

Published online: 07 December 2020

\section{References}

1. Fokkens WJ, Lund VJ, Mullol J, Bachert C, Alobid I, Baroody F, et al. EPOS 2012: European position paper on rhinosinusitis and nasal polyps 2012. A summary for otorhinolaryngologists. Rhinology. 2012;50:1-12. https://doi. org/10.4193/Rhino50E2.

2. Worrall G. Acute sinusitis. Can Fam Physician. 2011;57:565-7.

3. Orlandi RR, Kingdom TT, Hwang PH. International consensus statement on allergy and rhinology: rhinosinusitis executive summary. Int Forum Allergy Rhinol. 2016;6(Suppl 1):S3-21. https://doi.org/10.1002/alr.21694.

4. Sharma P, Finley R, Weese S, Glass-Kaastra S, Mclsaac W. Antibiotic prescriptions for outpatient acute rhinosinusitis in Canada, 2007-2013. PLoS One. 2017;12:e0181957. https://doi.org/10.1371/journal.pone.0181957.

5. Eisenberg DM, Davis RB, Ettner SL, Appel S, Wilkey S, Van Rompay M, et al. Trends in alternative medicine use in the United States, 1990-1997: results of a follow-up national survey. JAMA. 1998;280:1569-75. https://doi.org/10. 1001/jama.280.18.1569.

6. Guo R, Pittler MH, Ernst E. Herbal medicines for the treatment of allergic rhinitis: a systematic review. Ann Allergy Asthma Immunol. 2007:99:483-95. https://doi.org/10.1016/S1081-1206(10)60375-4

7. Koch AK, Klose P, Lauche R, Cramer H, Baasch J, Dobos GJ, et al. A systematic review of phytotherapy for acute rhinosinusitis. Forsch Komplementmed. 2016:23:165-9. https://doi.org/10.1159/000447467.

8. Macchi A, Terranova P, Castelnuovo P. Recurrent acute rhinosinusitis: a single blind clinical study of $\mathrm{N}$-acetylcysteine vs ambroxol associated to corticosteroid therapy. Int J Immunopathol Pharmacol. 2012;25:207-17. https://doi.org/10.1177/039463201202500123.

9. Neubauer N, Marz RW. Placebo-controlled, randomized double-blind clinical trial with Sinupret(R) sugar coated tablets on the basis of a therapy with antibiotics and decongestant nasal drops in acute sinusitis. Phytomedicine. 1994;1:177-81. https://doi.org/10.1016/S0944-7113(11)80061-9.

10. Rossi A, Dehm F, Kiesselbach C, Haunschild J, Sautebin L, Werz O. The novel Sinupret(R) dry extract exhibits anti-inflammatory effectiveness in vivo. Fitoterapia. 2012:83:715-20. https://doi.org/10.1016/j.fitote.2012.02.008.

11. Marz RW, Ismail C, Popp MA. Profile and effectiveness of a phytogenic combination preparation for treatment of sinusitis. Wien Med Wochenschr. 1999;149:202-8.

12. Melzer J, Saller R, Schapowal A, Brignoli R. Systematic review of clinical data with BNO-101 (Sinupret) in the treatment of sinusitis. Forsch Komplementmed. 2006;13:78-87. https://doi.org/10.1159/000091969.

13. Jund R, Mondigler M, Stammer H, Stierna P, Bachert C. Herbal drug BNO 1016 is safe and effective in the treatment of acute viral rhinosinusitis. Acta Otolaryngol. 2015;135:42-50. https://doi.org/10.3109/00016489.2014.952047.

14. Jund R, Mondigler M, Steindl H, Stammer H, Stierna P, Bachert C, et al. Clinical efficacy of a dry extract of five herbal drugs in acute viral rhinosinusitis. Rhinology. 2012:50:417-26. https:/doi.org/10.4193/Rhino12.015.
15. Jund R, Mondigler M, Steindl $H$, Stammer $H$, Stierna P, Bachert C. Clinical efficacy of a herbal drug combination in acute viral rhinosinusitis. MMW Fortschr Med. 2015;157:6-11. https://doi.org/10.1007/s15006-015-2934-4.

16. Passali D, Loglisci M, Passali GC, Cassano P, Rodriguez HA, Bellussi LM. A prospective open-label study to assess the efficacy and safety of a herbal medicinal product (Sinupret) in patients with acute rhinosinusitis. ORL J Otorhinolaryngol Relat Spec. 2015;77:27-32. https://doi.org/10.1159/ 000370123.

17. Weber U, Luedtke R, Friese KH, Fischer I, Moeller H. A non-randomised pilot study to compare complementary and conventional treatments of acute sinusitis. Forsch Komplementarmed Klass Naturheilkd. 2002:9:99-104. https:// doi.org/10.1159/000057271.

18. Schoetz K, Erdelmeier C, Germer S, Hauer H. A detailed view on the constituents of EPs 7630. Planta Med. 2008;74:667-74. https://doi.org/10. 1055/s-2008-1074515.

19. Bladt S, Wagner H. From the Zulu medicine to the European phytomedicine Umckaloabo. Phytomedicine. 2007;14(Suppl 6):2-4. https://doi.org/10.1016/j. phymed.2006.11.030

20. Kayser $\mathrm{O}$, Kolodziej $\mathrm{H}$, Kiderlen AF. Immunomodulatory principles of Pelargonium sidoides. Phytother Res. 2001;15:122-6. https://doi.org/10.1002/ptr.785.

21. Michaelis $M$, Doerr HW, Cinatl J Jr. Investigation of the influence of EPs(R) 7630, a herbal drug preparation from Pelargonium sidoides, on replication of a broad panel of respiratory viruses. Phytomedicine. 2011;18:384-6. https://doi.org/10.1016/j.phymed.2010.09.008.

22. Lizogub VG, Riley DS, Heger M. Efficacy of a pelargonium sidoides preparation in patients with the common cold: a randomized, double blind, placebo-controlled clinical trial. Explore (NY). 2007;3:573-84. https://doi.org/ 10.1016/j.explore.2007.09.004

23. Riley DS, Lizogub VG, Zimmermann A, Funk P, Lehmacher W. Efficacy and tolerability of high-dose pelargonium extract in patients with the common cold. Altern Ther Health Med. 2018;24:16-26.

24. Bachert C, Schapowal A, Funk P, Kieser M. Treatment of acute rhinosinusitis with the preparation from Pelargonium sidoides EPs 7630: a randomized, double-blind, placebo-controlled trial. Rhinology. 2009;47:51-8.

25. Peric A, Gacesa D, Barac A, Sotirovic J, Peric AV. Herbal drug EPs 7630 versus amoxicillin in patients with uncomplicated acute bacterial rhinosinusitis: a randomized, open-label study. Ann Otol Rhinol Laryngol. 2020;129:969-76. https://doi.org/10.1177/0003489420918266.

26. Mullol J, Crespo C, Carre C, Brosa M. Pharmacoeconomics of Cyclamen europaeum in the management of acute rhinosinusitis. Laryngoscope. 2013; 123:2620-5. https://doi.org/10.1002/lary.24167.

27. Pfaar O, Mullol J, Anders C, Hormann K, Klimek L. Cyclamen europaeum nasal spray, a novel phytotherapeutic product for the management of acute rhinosinusitis: a randomized double-blind, placebo-controlled trial. Rhinology. 2012:50:37-44. https://doi.org/10.4193/Rhino10.096.

28. Ponikau JU, Hamilos DL, Barreto A, Cecil J, Jones SW, Manthei SE, et al. An exploratory trial of Cyclamen europaeum extract for acute rhinosinusitis. Laryngoscope. 2012;122:1887-92. https://doi.org/10.1002/lary.23366.

29. Gedevanishvili MD, Gogitidze NM, Sikharulidze IS. Reflex mechanisms of nasoparanasal secretion in administration of sinuforte. Vestn Otorinolaringol. 2007:(3):54-5.

30. Zalmanovici Trestioreanu A, Barua A, Pertzov B. Cyclamen europaeum extract for acute sinusitis. Cochrane Database Syst Rev. 2018;5:CD011341. https://doi.org/10.1002/14651858.CD011341.pub2.

31. Gottschlich S, Roschmann K, Candler H. Phytomedicines in acute rhinosinusitis: a prospective, non-interventional parallel-group trial. Adv Ther. 2018;35:1023-34. https://doi.org/10.1007/s12325-018-0736-7.

32. Rantzsch U, Vacca G, Duck R, Gillissen A. Anti-inflammatory effects of Myrtol standardized and other essential oils on alveolar macrophages from patients with chronic obstructive pulmonary disease. Eur J Med Res. 2009; 14(Suppl 4):205-9. https://doi.org/10.1186/2047-783x-14-s4-205.

33. Christoph F, Kaulfers PM, Stahl-Biskup E. In vitro evaluation of the antibacterial activity of beta-triketones admixed to Melaleuca oils. Planta Med. 2001;67:768-71. https://doi.org/10.1055/s-2001-18350.

34. Behrbohm H, Kaschke O, Sydow K. Effect of the phytogenic secretolytic drug Gelomyrtol forte on mucociliary clearance of the maxillary sinus. Laryngorhinootologie. 1995;74:733-7. https://doi.org/10.1055/s-2007-997835.

35. Meister R, Wittig T, Beuscher N, de Mey C. Efficacy and tolerability of myrtol standardized in long-term treatment of chronic bronchitis. A double-blind, placebo-controlled study. Study Group Investigators. Arzneimittelforschung. 1999;49:351-8. https://doi.org/10.1055/s-0031-1300426. 
36. Gillissen A, Wittig T, Ehmen M, Krezdorn HG, de Mey C. A multi-centre, randomised, double-blind, placebo-controlled clinical trial on the efficacy and tolerability of GeloMyrtol(R) forte in acute bronchitis. Drug Res (Stuttg). 2013:63:19-27. https://doi.org/10.1055/s-0032-1331182.

37. Federspil P, Wulkow R, Zimmermann T. Effects of standardized Myrtol in therapy of acute sinusitis--results of a double-blind, randomized multicenter study compared with placebo. Laryngorhinootologie. 1997;76:23-7. https:// doi.org/10.1055/s-2007-997381.

38. Kehrl W, Sonnemann U, Dethlefsen U. Therapy for acute nonpurulent rhinosinusitis with cineole: results of a double-blind, randomized, placebocontrolled trial. Laryngoscope. 2004;114:738-42. https://doi.org/10.1097/ 00005537-200404000-00027.

39. Paparoupa M, Gillissen A. Is Myrtol(R) standardized a new altemative toward antibiotics? Pharmacogn Rev. 2016;10:143-6. https:/doi.org/10.4103/0973-7847.194045.

40. Aldoghaim FS, Flematti GR, Hammer KA. Antimicrobial activity of several cineole-rich Western Australian Eucalyptus essential oils. Microorganisms. 2018;6. https://doi.org/10.3390/microorganisms6040122.

41. Yadav N, Chandra H. Suppression of inflammatory and infection responses in lung macrophages by eucalyptus oil and its constituent 1,8-cineole: role of pattern recognition receptors TREM- 1 and NLRP3, the MAP kinase regulator MKP-1, and NFkappaB. PLoS One. 2017;12:e0188232. https://doi. org/10.1371/journal.pone.0188232.

42. Juergens UR. Anti-inflammatory properties of the monoterpene 1.8-cineole: current evidence for co-medication in inflammatory airway diseases. Drug Res (Stuttg). 2014;64:638-46. https://doi.org/10.1055/s-0034-1372609.

43. Tesche S, Metternich F, Sonnemann U, Engelke JC, Dethlefsen U. The value of herbal medicines in the treatment of acute non-purulent rhinosinusitis. Results of a double-blind, randomised, controlled trial. Eur Arch Otorhinolaryngol. 2008;265:1355-9. https://doi.org/10.1007/s00405-008-0683-z.

44. Bachert C, Thakur M, Weyers S, Bittner C, Abramov-Sommariva D. Reporting clinical trial results of phytomedicines in acute rhinosinusitis: letter to the editor regarding Gottschlich S, Roschmann K, Candler H. Adv Ther (2018); 35:1023-1034. doi: 10.1007/s12325-018-0736-7. Adv Ther. 2019;36:1011-3. https://doi.org/10.1007/s12325-019-00933-6.

45. Passali D, Spinosi MC, Crisanti A, Bellussi LM. Mometasone furoate nasal spray: a systematic review. Multidiscip Respir Med. 2016;11:18. https://doi. org/10.1186/s40248-016-0054-3.

46. Meltzer EO, Charous BL, Busse WW, Zinreich SJ, Lorber RR, Danzig MR. Added relief in the treatment of acute recurrent sinusitis with adjunctive mometasone furoate nasal spray. The Nasonex Sinusitis Group. J Allergy Clin Immunol. 2000;106:630-7. https://doi.org/10.1067/mai.2000.109056.

47. Nayak AS, Settipane GA, Pedinoff A, Charous BL, Meltzer EO, Busse WW, et al. Effective dose range of mometasone furoate nasal spray in the treatment of acute rhinosinusitis. Ann Allergy Asthma Immunol. 2002;89: 271-8. https://doi.org/10.1016/S1081-1206(10)61954-0.

48. Meltzer EO, Bachert $\mathrm{C}$, Staudinger $\mathrm{H}$. Treating acute rhinosinusitis: comparing efficacy and safety of mometasone furoate nasal spray, amoxicillin, and placebo. J Allergy Clin Immunol. 2005;116:1289-95. https:// doi.org/10.1016/j.jaci.2005.08.044.

49. Bachert C, Meltzer EO. Effect of mometasone furoate nasal spray on quality of life of patients with acute rhinosinusitis. Rhinology. 2007:45:190-6.

50. Meltzer EO, Gates D, Bachert C. Mometasone furoate nasal spray increases the number of minimal-symptom days in patients with acute rhinosinusitis. Ann Allergy Asthma Immunol. 2012;108:275-9. https://doi.org/10.1016/j.anai.2012.01.015.

51. Zalmanovici Trestioreanu A, Yaphe J. Intranasal steroids for acute sinusitis. Cochrane Database Syst Rev. 2013:CD005149. https://doi.org/10.1002/ 14651858.CD005149.pub4.

52. Blasi F, Page C, Rossolini GM, Pallecchi L, Matera MG, Rogliani P, et al. The effect of $\mathrm{N}$-acetylcysteine on biofilms: implications for the treatment of respiratory tract infections. Respir Med. 2016;117:190-7. https:/doi.org/10.1016/j.rmed.2016.06.015.

53. Sadowska AM, Verbraecken J, Darquennes K, De Backer WA. Role of Nacetylcysteine in the management of COPD. Int J Chron Obstruct Pulmon Dis. 2006;1:425-34. https://doi.org/10.2147/copd.2006.1.4.425.

54. Bahtouee M, Monavarsadegh G, Ahmadipour M, Motieilangroodi M, Motamed N, Saberifard J, et al. Acetylcysteine in the treatment of subacute sinusitis: a double-blind placebo-controlled clinical trial. Ear Nose Throat J. 2017;96:E7-E11. https://doi.org/10.1177/014556131709600102.

\section{Publisher's Note}

Springer Nature remains neutral with regard to jurisdictional claims in published maps and institutional affiliations.

\section{Submit your manuscript to a SpringerOpen ${ }^{\circ}$ journal and benefit from:}

- Convenient online submission

- Rigorous peer review

- Open access: articles freely available online

- High visibility within the field

- Retaining the copyright to your article

Submit your next manuscript at $\boldsymbol{\nabla}$ springeropen.com 